\title{
Challenges faced by gay, lesbian, bisexual and transgender (glbt) students at a South African university
}

\author{
S SITHOLE
}

\begin{abstract}
This article explores the academic and social challenges experienced by students from the gay, lesbian, bisexual and transgender (glbt) community on campus at a South African university. A qualitative study to investigate some of these academic and social challenges experienced by glbt students at a university campus was conducted. The population of the study was all students from glbt community on campus and a purposive sample of twelve (12) respondents was constituted and a semi-structured interview guide was designed and administered to all twelve (12) participants. Data were audio recorded and transcribed. Content analysis which is a method used to systematically analyse the meaning of communications was used to analyse data. Of central interest were the core themes that speakers referred to, the information or messages that they wanted to pass on to their audience. The findings suggest that glbt students grapple with issues such as labelling, sexual abuse, discrimination/marginalisation and unfairness in the allocation of resources such as accommodation. In response to these cancerous societal ills, the helping professions exhort practitioners to empower vulnerable populations, promote social justice, support client self-determination and keep abreast of current knowledge relevant to professional practice. This article concludes with a set of recommendations on some of the strategies to address the identified socio-academic challenges.
\end{abstract}

Keywords: gay, lesbian, bisexual, transgender, socio-academic challenges, South African university

\section{Introduction}

The South African constitution is the bastion of democracy in South Africa. As a supreme law that governs relationships between persons, and between persons and institutions/organizations, and relationships between three pillars of the state: the judiciary, the legislature and the executive it therefore it prescribes to the South African populace to treat and relate with one another on the plane of equality. Yet, for a developing society in transition such as South Africa, two decades of democracy seem not to have adequately permeated and pervaded the psyche of the people. One area that still begrudgingly and intransigently begs serious attention is the thorny issue of how the South African society treats sexual minorities, in particular the glbt community. Whereas freedom is sometimes undeniably an evasive and vague reality for those at the receiving end of prejudice as a result of naturally endowed attributes or factors that are obviously (not to all) beyond their control such as sexual orientation, South Africa remains a country of missed opportunities replete with a myriad of contradictions. Given that advanced developed societies such as the United States have grappled somewhat with issues of sexual minorities in universities which are the intellectual repositories and incubators of potent ideas for future leaders, (South) Africa still has a lot to prove that its constitution which prohibits discrimination on the basis of sexual 
orientation, is worth the many (self) sacrifices by most of our iconic leaders who have departed our tortured planet. Research on this topical issues of rights to citizenship of glbt students have been subject of scientific investigation (Robert, 2002; Rankin, 2003). Inter alia, Snowdown (2003) examines methods of improving the climate for glbt students; and, Kiekel (2012) investigates support and engagement for lgbt students. Unmistakenly, this article is an additional voice in the discourse on inalienable rights of those who continue to be persecuted by a civilised yet homophobic society.

\section{Problematising discrimination in societies}

A large portion of social work clients come from minority communities. However, there are those minority groups who tend to be neglected and rejected more than others, yet sadly, they are part of the entire society, battling in whatever way possible to make South Africa a better world by also un/intentionally weaving the new social fabric. The social treatment of ethnic minorities, foreigners, homosexuals, women, the handicapped, the elderly and other groups with perceived low or no social power is a mirror of the dys-functionality of society, reflecting prevailing and dominant mentalities in a specific geographic or cultural context. These mentalities and attitudes are informed by hegemonic beliefs, which shape everyday human relationships and everyday practices of various institutions that determine people's destinies (Leskošek, 2009: 125). Misogyny, racial discrimination and homophobia are dominant philosophies for some sections of the population. Homophobia is a prevalent and topical problem in South Africa, and institutions of higher learning are not immune from such stereotypes, the assumed level of intellectual development notwithstanding.

As sexual minorities, the glbt community on South African campuses still experiences notions of "Who is outside and who is inside?", "who belongs among us and who does not", and "those who dominate and those who are dominated have all to lose if the current disorders continue" (Fanon-Mendes France, n.d.: 8; Soudien, 2014: 912). These issues of meta-narratives, mentalities and identities still pose a major challenge among students across university campuses in South Africa. Mentality is a specific manner of thinking and feeling among a group of people. It is a manner of understanding, experiencing, and evaluating (Sruk, 1980: 211). Different groups in society think differently and develop different mentalities; and, those that are supported by the majority become the dominant ones (Leskošek, 2009). The current article explores the challenges experienced by sexual minorities within a specific campus in South Africa, under circumstances where there is a dearth of literature on this controversial issue. Yet, perceptions of campus social environment has an impact on academic performance of students (Kuh, 2001, 2003, 2009).

\section{Theoretical framework}

For this article, the concept of otherness, which is a set of ideas that demonstrates that labelling leads to disadvantage is used to illuminate some of the challenges that afflict the glbt community on campus. The notion of otherness is used by sociologists to highlight how social identities are contested. This concept is also used to break down the ideologies and resources that groups use to maintain their social identities (Zevallos, 2013: 3). Needless to say that sexual orientation is used to form an identity. Quite often, people relate to one another on the basis of how they perceive one another through the lens of sexual orientation. The negotiation of identity therefore depends upon the negotiation of power relationships (Zevallos, 2011: 3).

Okollie (2003: 2) puts it thus: 
"Social identities are relational; groups typically define themselves in relation to others. This is because identity has little meaning without the 'other'. So, by defining itself, a group defines others. Identity is rarely claimed or assigned for its own sake. These definitions of self and others have purposes and consequences. They are tied to rewards and punishment, which may be material or symbolic. There is usually an expectation of gain or loss as a consequence of identity claims. This is why identities are contested. Power is implicated here, and because groups do not have equal powers to define both self and other, the consequences reflect these power differentials. Often, notions of superiority and inferiority are embedded in particular identities".

Homophobia, xenophobia, racism as well as gender discrimination are manifestations of otherness. The issue of otherness was first made a relevant subject within structural anthropology and its approach as a linguistic system (Leskošek, 2009). The other is constituted in a manner that it appears as a foreign body in a dominant culture, and therefore needs to be removed if culture is to be healed. Moore (1995: 16-20) explains this using the concept of cultural pollution, which forces certain groups of people into a subordinate position or even excludes them entirely, an undesirable philosophy that led to some of the worst human miseries in living memory, such as the Jewish pogrom and the genocide in Rwanda. The cultural pollution theory refers to a set of beliefs that a collective body of people can be contaminated by the other to such an extent that its existence becomes threatened. The aim of this article is to examine academic and social challenges faced by the glbt community at South African universities; and, to propose intervention guidelines for institutions and organisations.

\section{Research design}

The study was exploratory and qualitative. A sample of twelve (12) students was selected purposively from a glbt support group on campus of the University of Limpopo. Semistructured interviews were conducted with each participant; and, content analysis was performed. The main themes that emerged from data analysis are as follows: labelling or name calling; exclusion by religious institutions; experiences of sexual abuse; exclusion and discrimination by fellow students; marginalization by academic instructors; and, unequal access in as far as allocation of resources are concerned.

\section{Demographic description of the sample}

The findings indicated that most members of the glbt students in the sample were single, because societies consider homosexual unions inappropriate and a minority (8\%) were married to heterosexual partners, but continued to show interest and get attracted to persons of the same sex. The most important reason for their single status could be as a result of their age and the fact that they had pursued tertiary education. At a more complex level, the single status could be as a result of unresolved social identity issues or not having come out, and therefore being hamstrung in expressing their dating and sexual preferences. Inability to come out in the open is a source of continuous and continual psychological conflict and finding it difficult to cope with university life. Thio (2004: 413) suggests that such people could be termed bisexual because they are inhibited to express their true sexual orientation. This is considered unhealthy for these people in that they do not live their true lives and identities. The other reason for the participants' single marital status could be that they were students and therefore still had a few years before they could marry. 
Most students interviewed were affiliated to churches, contrary to some positions on this from other sources (Webb \& Tossel, 2003: 187). The findings also revealed that most students were not comfortable to disclose or come out within the church as the latter institution considers homosexuality blasphemous, heretical and therefore an abomination. The age range of the participants was from 18-21. Needless to say this is the time when most people obtain a chance to go through their tertiary education. For most people, this age range is a period of self-discovery and choosing a future soul-mate. However, for glbt students, this is the period at which most of them have to deal with intra-personal conflict of coming out in the open.

There seems to be a positive relationship between self-discovery and the level of education among glbt students. There is little self-discovery at primary level (9\%), more at secondary level (33\%) and the greatest happens at tertiary level (58\%).

\section{Labelling}

Labeling often takes a very subtle form and may extend to micro-aggression. Microaggressions are subtle, non-verbal, or even preconscious daily actions that marginalize members of underrepresented groups. As multiple events, these acts may go unnoticed or may be forgotten. However, over time, persistence of micro-aggressions contributes to a constant subtext of threat and stress for members of underrepresented groups (Kiekel, 2012). Most (67\%) of the respondents reported that they were labelled by fellow students whilst 33\% never had demeaning and derogatory labels attached to them. Some of the labels used towards people in the lgbt community are trassies, an Afrikaans word for a homosexual or isitabane, a Nguni word for homosexual. One also needs to submit that such labelling are too simplistic and at most demonstrate inadequate comprehension of the glbt community. It is indeed difficult or rather impossible to determine the real orientation of a person by merely observing his/her outward appearance. In most cases, knowing the real status of a person is a function of the particular individual informing you; and, this does not happen that easily. There should be a serious element of trust before this disclosure occurs. So often at times, they are insulted several times by inaccurate labelling of their real sexual orientation and by derogatory labels that go with this misunderstanding.

As a result of this negative labelling and stigmatisation, students of the glbt community would invariably find it difficult to come out. The labelling theory suggests that society views members of the glbt community as sick and sinful, they are stigmatised with unfortunate circumstances (Weinberg, Ruinton \& Hammersmith, 2006: 192). Labels attached to sexual minorities are derived from dominant social discourses and meta-narratives and they form social identities which are relational (Okolie, 2003:2). But even these social identities are contested. Students from the glbt community are seen by some as a foreign body in a dominant culture, which is what Moore (1995: 16) calls cultural pollution. The findings at the University of Nebraska and Lincoln University Climate Assessment for glbt indicate that $30 \%$ had verbal attacks hurled at them, with $21 \%$ indicating this happened more than five times in one academic year. Three percent (3\%) had been threatened with physical violence and nine percent $(9 \%)$ had their personal property damaged or destroyed. None reported having objects thrown at them or having been physically assaulted. 


\section{Experience of sexual abuse}

Fifty five percent (55\%) of the respondents reported that they were never exposed to sexual abuse, while the other $45 \%$ had been. Sexual abuse in this regard would, include, among others, rape, or what is called "corrective rape" in South Africa. Perpetrators of "corrective rape" believe that forcing themselves on lesbians would result in the latter becoming straight and therefore rehabilitated or rather cured from the "abnormality" of homosexuality. The rape of lesbians can be understood from the otherness notion (Leskosek, 2009) where the other is perceived as a foreign body to a dominant culture; and, this foreign body needs to be removed for culture to be healed of pollution or contamination. Hence, the mistaken belief among the perpetrators of corrective rape that they can get rid of lesbians as well as their "condition" and heal society. The commission of "corrective rape" claimed the innocent and young life of a thirteen year old lesbian from Atteridgeville Township west of Pretoria.

Members of the glbt community report that sometimes they experience sexual molestation. Webb \& Tossel (2003: 127) maintain that members of the glbt community are subjected to personal abuse ranging from insults and derogatory remarks to actual physical and sexual abuse which may extend to murder. The findings from the study indicated that $25 \%$ of the respondents were raped and 33\% were subjected to harassment. Literature supports the finding that members of the glbt community are often exposed to harassment and teasing. Sexual harassment includes any kind of behaviour which makes one uncomfortable: it may also extend to unwelcome sexual jokes and rude gestures (Thio, 2004: 154; Hurst, 2010: 134).

\section{Marginalisation by lecturers}

Some students from the glbt community reported that they were marginalised by the teaching staff at the university. Sixty seven percent (67\%) of the respondents from this sample reported feelings of being deliberately isolated by their lecturers, whilst the $33 \%$ did not feel the same way. Marginalisation, according to these students, took the form of, inter alia, exclusion from class discussions. Students complained that they could not participate in class discussions. When they raised a hand to answer a question, for example, they would often be ignored. This, according to them is like "being forced to swallow a bitter pill". The participants also reported being excluded from some validating minor academic errands that lecturers gave to "straight" students. As if that were not enough, glbt students also reported that their ideas were looked down upon. One of the participants' responses was, "our ideas are also perceived as lopsided just like our sexual orientation". The situation painted above is a clear assault of social justice because it is characterised by a lack of what Nancy Fraser defines as "parity of participation" (Tikly, 2010: 6).

One respondent shared with the researcher a scenario where the students were required to make a joint presentation in class as a form of their formative assessment. After the students had made their presentation, the female lecturer in charge of the class made the following crass remark, "Men who wear nail polish are not male enough". This, inevitably, did not sit well with one of the participants in this study. This homophobic remark by the lecturer, expressed deep sentiments of hetero-sexism or heterosexual bias (a subtle discrimination against perceived minorities), which Morrow (1996: 2) describes as "the promotion and valuing of heterosexuality over non-heterosexuality by carefully privileging those who have a gay (or) lesbian...identity”. Berkman \& Zinberg (1997: 320) explain hetero-sexism thus: 
"Heterosexual bias is a more subtle concept than homophobia and entails the belief that heterosexuality is normative and that non-heterosexuality is deviant and intrinsically less desirable. Hetero-sexism is often manifested by individuals who would not be considered as being blatantly homophobic or holding negative attitudes. This often subtle hetero-sexism permeates the culture in which social institutions and social work practice are built".

The reported negative remarks towards glbt students on this campus are reminiscent of those at UNL Campus Community where glbt students recounted negative statements from faculty 6\%, 5\% from Student Affairs Members, 17\% from university staff members and 80\% from other students (Brown, 2002).

\section{Exclusion by other students}

Students who belong to the glbt community do not only experience discrimination from the teaching staff, but from fellow students as well. Occasionally lecturers give students group assignments, tasks or research projects for whatever reason. An average group in this instance would be made up of about five students. In response to these instructions, heterosexual students would more often than not, not allow homosexual students to join their groups. It is as if the homosexual students have to kneel down and beg for inclusion in such academic group activities.

Zevallos (2011: 31) and Okolie (2003: 2) opine that the heterosexual students use groups to maintain social identities which are relational. So, by excluding others, this group defines itself, and these definitions of self and others have consequences that are tied to rewards and punishment which may be material or symbolic. Such discriminatory and exclusionary incidents, however, succeed in further denting and eroding the self-esteem of these glbt students and surely this, in, my opinion, would contribute to poor academic performance of these students. When such happens, the words of the poet, Heaney (1991), gore at our inner being:

"Human beings suffer.

They torture one another.

They get hurt and get hard.

No poem or play or song.

Can fully right a wrong inflicted and endured".

\section{Discrimination by fellow students}

Most respondents (75\%) in the sample stated that they were discriminated against by their peers and $25 \%$ did not feel the same way. The students who felt victims of discrimination cited the same factors as those observed by Eitzen \& Zinn (2003: 308) where members of glbt community are perceived as objects of derision and contempt. The participants also reported an occasion when students on campus had organized a festival and competition on indigenous/traditional games. It is alleged that most heterosexual students did not want to play with members of the glbt community. Discriminatory practices also manifested themselves through peers' refusal to communicate with members of the glbt community. 
Invariably, most respondents expressed shock at the level of callousness and ignorance about sexuality issues on campus and suggested that there should be more awareness campaigns in this regard.

\section{Discrimination from worship}

Undeniably, South Africa is a secular state but the majority of her citizens are Christian (Census Report, 2012). Following from this then, most gays and lesbians would be from Christian backgrounds, and they experience discrimination from places where they were born and raised and this extends to their student lives. The glbt students complain about the stares, gossips, derisions, teasing and other homophobic tendencies from church members with whom they worship. Such micro-aggressions make it difficult for members to worship freely in a country that abhors discrimination of whatever kind in terms of section 9(3) of the Constitution of the Republic of South Africa, 1996, which states: The state may not unfairly discriminate directly or indirectly against anyone on one or more grounds, including race, gender, sex, pregnancy, marital status, ethnic or social origin, colour, sexual orientation, age, disability, religion, conscience, belief, culture, language and birth. One would expect citizens of a country like South Africa, which had been in the firm clasp of racial discrimination for almost three hundred years, and was consequently declared a pariah state as a result, to eschew any form of discrimination as instructed by the constitution. But, lo and behold, discriminatory tendencies and practices are still part of the South African higher education landscape.

\section{Allocation of residences}

Residences on this particular campus are "integrated" in terms of gender. In the case of stacked buildings each floor would be allocated according to gender, meaning that males occupy their own floor apart from females. Now, glbt students are discriminated by fellow students in residences. Some homosexual male students do not prefer to share residences with gay students, and their reasons would be that gay students propose love to them, touch them inappropriately, make sexist and seductive remarks towards them. Some male students are allegedly embarrassed by all this and that is why they resent living among gay students.

\section{Unequal treatment in health facilities}

Findings from this study suggest that $58 \%$ of the respondents felt that they were treated unequally and $42 \%$ did not have a problem with the personal treatment from health facilities on campus. Literature suggests that gays and lesbians are on the receiving end of unequal treatment from health facilities, and that the students often feel uncomfortable having to communicate with staff in such facilities. The source of the discomfort is that students are scared that they may come out unintentionally or receive less favourable treatment from such encounters (Mathieson, Bailey \& Gurevich, 2002; Benokraitis 2005; Kolmes, Stocks \& Moser, 2006; Pitts, Smith, Mitchell \& Patel, 2006; Edwards \& van Roekel, 2009). Those who eventually use campus health services may not divulge their sexuality and this may mean information relevant for treatment is not provided (Mc Nair, 2000). Alternatively, where health care providers know their patient's sexual orientation, stereotyped views may lead to sub-optimal treatment (Meyer, 2001). The latter part of the previous statement confirms the observation by Sir Douglas Black (DHSS, 1980) that social class is a key determinant of people's life chances. 
The Survey of Violence and Discrimination against sexual minorities by Wright (2009) which was completed by members of BDSM (bondage-discipline, dominance-submission, sado masochism) leather and fetish communities $(\mathrm{N}=3058)$ found that nearly half the sample reported being discriminated against by a medical doctor, and $40 \%$ by a mental health practitioner.

\section{Conclusion}

The findings in this article demonstrate that sexual minorities, in this regard, glbt students still face a lot of rejection by their fellow students and to some extent their academic instructors. Evidently, this shows that campus life, more especially among students, does not as yet embrace the value of diversity in its various dimensions. This, undeniably, an indictment of a university as a repository for progressive ideas, and a sad reflection of a homophobic society that we continue to live in, twenty years after the scourge of (racial) exclusion. Indeed, Nelson Mandela's observation is apt: I have walked that long road to freedom. I have tried not to falter; I have made mis-steps along the way. But I have discovered the secret that after climbing a great hill, one only finds that there are many more hills to climb. It is indeed true that after climbing a highest mountain such as overcoming an inhuman system was, we still grapple with issues of otherness such as homophobia. This is made so starkly clear when one learns that participants in this study were religious in that they belonged to a variety of churches yet, most felt unwelcome in these institutions for the troubled souls, yet feel rejected. The church, largely, in South Africa still grapples with the polemic issue of sexual orientation of its members so much so that some churches have split. Little wonder that, glbt students whinged about micro-aggressions meted out to them in the form of stares, gossip, derision, teasing and other homophobic tendencies from other church members.

Inequality, explicitly and implicitly expressed through various forms of marginalization of glbt students by some lecturers and blatant exclusion by some students from academic activities is a clear demonstration of "otherness", and confirms that our campuses and to a large extent our society is far from being fully integrated and equal. Needless to say that such attitude continues to gradually erode our social fabric, which factor is a gnawing threat to the country's stability. Society and particularly universities which are founded on autonomy and freedom of inquiry must be propelled by values of equality as well as freedom of association amongst others. Morrow (1989: 13) maintains that the principle of equality requires not that all people should be treated in the same way, but that people should not be treated differently unless relevant grounds for such differences have been provided.

Unlike during the epoch of racial discrimination, there is a modicum of freedom on South African campuses. However, this freedom is not extended to all, least of these are the sexual/ minorities. Oxlund (2009) made this poignant observation about political freedom in of South African universities, "although political discourses have changed dramatically since the demise of Apartheid, the material realities on the ground have only changed marginally". This fact attests to, inter alia, the fact that the sexual/minorities are still to fully enjoy the fruits that freedom brought. Fortunately enough, each problem that assails society is accompanied by an alternative, even though society may have to search the proverbial needle in the haystack to find it. 


\section{Recommendations}

On the basis of findings from this research, it is suggested that further research be conducted to enquire exclusively, into the academic performance of students in the glbt community, in particular, to investigate the correlation between membership within glbt and academic performance. As South Africa, celebrates more than twenty years of democracy, it may be important to have a robust national debate on diversity, to bring to the fore some of the salient problems that have been conveniently swept under the carpet as the populace dealt with issues of racial exclusion. Soudien (2014: 910-914) advocates for progressivism as an anti-dote to some of the socio-academic ills bedevilling higher education in South Africa. Progressivism is "informed by a commitment to the weak, the poor and the marginalized". Anyway, "Much of how it projects itself is premised on the belief that human beings have the ability, through purposeful action, to improve their environments and conditions of their lives" (Soudien, 2014: 910). To some extent, this idea of progressivism may be extended to imply that universities as hegemonic and elitist institutions must always be sensitive to the needs and often frustrations of minority communities within their campuses. Hence, Soudien (2014: 913) concludes his discussion by saying "it is necessary to emphasise why the idea of the progressive is important for the South African university to cultivate".

Progressivism is akin to social justice. The concept demands that people have equal rights and opportunities; for everyone, from the poorest person on the margins of society to the wealthiest, deserves an even playing field (Miller, 1991: 1; Mafumo, 2011: 1554; Mashabela, 2011: 1584; Hlalele \& Alexander, 2012: 489). Social justice is inextricably aligned to need, desert and equality. It therefore seems plausible, according to Waghid (2014: 1448), to claim that higher education for social justice ought to be responsive to the same demands mentioned above. One of the critical means of ensuring integration of the glbt community is to elevate and entrench the notion of citizenship. Enslin (2000: 299) notes that citizenship encompass: common membership in a unified society in which difference is respected; the enjoyment of extensive range of rights and freedoms.

In concretising a winning battle plan for our universities, issues of diversity must constitute part of the curriculum right at first year level. To this extent, universities must as a matter of urgency conduct awareness campaigns on diversity issues annually. More ground will be covered if staff at the student counselling centre and the university health centre staff is trained on diversity issues, particularly as it relates to these glbt matters. Snowden (2003) also provided a blue print to counter homophobia in universities by proposing the following:

- Include sexual orientation and gender identity in the institution's non-discrimination policy

- If your school offers accommodation to students, ensure that it is open to glbt people on the same basis as it is open to all

- Check the language of institutional policies and procedures for glbt inclusion

- Provide specialized transgender training to institutional leaders and all relevant staff

- Designate a point-person for transgender related needs

- Allow glbt students to self-identify on surveys and forms

- When holding diversity celebrations be mindful of glbt inclusion

- Make activities for information seekers, applicants and admitted but undecided students glbt inclusive

- Recruit glbt and glbt knowledgeable students and employees to be admissions reviewers and interviewers. 


\section{References}

Berg, B.L. 2004. Qualitative Research Methods for the Social Sciences, $5^{\text {th }}$ edn. Boston: Allyn and Bacon Publishers.

Berkman, C.S. \& Zinberg, C. 1997. Homophobia and heterosexism in social workers. Social Work, 42(4): 319-333.

Benokraitis, N.V. 2005. Marriages and Families: Changes, Choices and Constraints, $3^{\text {rd }}$ edn. Baltimore: University of Baltimore.

Bless, C., Higson-Smith, C. \& Sithole, S.L. 2013. Fundamentals of Social Research Methods: An African Perspective, $5^{\text {th }}$ edn. Cape Town: Juta.

Canadian Association of Social Workers, 1995. Guidelines for Ethical Practice. Ottawa: Canadian Association of Social Workers.

Drower, S. 1990. Health care social work practice. In McKendrick, B.W. (ed.), Social Work in Action. Pretoria: Haum Tertiary.

Edwards, J. \& van Roekel, H. 2009. Gender, sexuality and embodiment: Access to and experience of health care by same -sex attracted women in Australia. Current Sociology, 57(2): 193-210.

Eitzen \& Zinn 2003. Social Problems, $5^{\text {th }}$ edn. New York: Pearsons Publishers.

Enslin, P. 2009. Defining a civic agenda: Citizenship and gender equality in post-apartheid education. In Arnot, M. \& Dillabough, J. (eds.), Challenging Democracy: International Perspectives on Gender, Education and Citizenship. London: Routledge Falmer, pp.297311.

Fanon-Mendes France, M. n.d. The contribution of Fanon to the process of the liberation of the people. The Black Scholar, 42(3-4): 8-12.

Hlalele, D. \& Alexander, G. 2012. University access, inclusion and social justice. South African Journal of Higher Education, 26(3): 487-502.

Hurst, C.E. 2010. Social inequality: Forms, Causes and Consequences, $7^{\text {th }}$ edn. New York: Pearsons Publishers.

Kolmes, K., Stock, W. \& Moser, C. 2006. Investigating bias in Psychotherapy with BDSM clients. Journal of Homosexuality, 50(2/3): 301-324.

Kuh, G.D. 2001. Organizational culture and student persistence: Prospects and puzzles. Journal of College Student Retention, 3: 23-39.

Kuh, G.D. 2003. What we're learning about student engagement from NSSE: Benchmarks for effective educational practices. Change, 35(2): 24-32.

Kuh, G.D. 2009. The national survey of student engagement: Conceptual and empirical foundations. New Directions for Institutional Research, 141: 5-20.

Leskošek, V. 2009. The Construction of the "Deviant Foreigner" and its Impact on Social Work in Theories and Methods of Social Work. Exploring different perspectives. Faculty of Social Work, University of Ljubljana. Slovenia. 
Mafumo, T.N. 2011. Social justice in South African universities: A bridge too far? South African Journal of Higher Education, 25(8): 1554-1562.

Malope, G. 2010. The Reality of our Freedom. Pretoria: Molaphole Publishers.

Mandela, N.R. 1995. Long Walk to Freedom. London: Back Bay Books.

Mandela, N.R. 2003. In his own words: From freedom to the future. London: Abacus.

Mashabela, N.T. 2011. Is democracy possible in university governance? A case of the University of Limpopo. South African Journal of Higher Education, 25(8): 1581-1591.

Mathieson, C., Bailey, N. \& Gurevich, M. 2002. Health care services for lesbian and bisexual women. Health Care for Women International, 23: 185-196.

McNair, R 2000. Lesbian sexuality: Do GPs contribute to lesbian invisibility and ill-health? Australian Family Physician, 29(6): 514-516.

Meyer, I. 2001. Why lesbian, gay, bisexual, and transgender public health? American Journal of Public Health, 91(6): 855-866.

Moore, H. 1995. Feminism and Anthropology. Minneapolis: University of Minnesota Press

Morrow, D.F. 1996. Heterosexism: Hidden discrimination in social work education. Journal of Gay and Lesbian Social Services, 5(4): 1-16.

Morrow, W. 1989. Chains of Thought. Johannesburg: Southern Book Publishers.

National Association of Social Workers, 1999. Code of Ethics. Washington DC: National Association of Social Workers.

Oxlund, B. 2009. Love in Limpopo: Becoming a man in a South African university campus. Unpublished PhD thesis Submitted to the Department of Anthropology, Faculty of Social Sciences, University of Copenhagen.

Pascal, G. 2007. Health and Health Policy. In Baldock, J., Manning, N. \& Vickerstaff, S. (eds.), Social Policy, $3^{\text {rd }}$ edn. Oxford: Oxford University Press.

Pitts, M., Smith, A., Mitchell, A. \& Patel, S. 2006. Private Lives: A Report on the Health and Well-being of GLBTI Australians. Melbourne: Australian Research Centre in Sex, Health and Society, La Trobe University.

Schlesinger, E.G. 1985. Health Care Social Work Practice: Concepts and Strategies. St Louis: Times Mirror/Mosby College Publishing.

Snowdown, S. 2003. Recommendations for Enhancing the Climate for LGBT Students and Employees in Health Professional Schools. A GLMA White Paper. GLMA: Health Professionals Advancing LGBT Equality, Washington DC.

Soudien, C. 2014. Inclusion, innovation and excellence: Higher Education in South Africa and its role in social development. South African Journal of Higher Education, 28(3): 907-922.

South African, 1996. The Constitution of the Republic of South Africa, Act 108 of 1996. Pretoria: Government Printers.

Sruk, V. 1980. Philosophical Terminology and Repertoire. Murska Sobota: Pomurska Zalozoba.

Thio, A 2004. Deviant Behaviour, $4^{\text {th }}$ edn. London: Harper Collins College Publishers. 
Tikly, L. 2006. A roadblock to social justice? An analysis and critique of the South African education roadmap. International Journal of Educational Development, Doi:10.106/j.ijedudev.2010. 06.008

Waghid, Z. 2014. Education for social justice through sustaianable development, economic development and equity. South African Journal of Higher Education, 28(4): 1448-1463.

Weinberg, M.S., Rubington, E. \& Hammersmith, S.K. 2006. The Solutions of Social Problems: Five Perspectives, $2^{\text {nd }}$ edn. Oxford: Oxford University Press.

Williams, D.J. 2012. Social Work, BDSM, and Vampires: Toward Empowering People with Non-traditional Identities. Ottawa: Canadian Social Work.

Williams, D.J. \& Prior, E. 2015. Do we always practice what we preach? Real Vampires fears of coming out of the coffin to social workers and helping professionals. Critical Social Work, (1): 79-82.

Zevallos, Z. 2011. What is Otherness? The Other Sociologist: Analysis of Difference. http://othersociologist.com/otherness-resources [Accessed: 04 May 2015].

\title{
Afrophobia, moral and political disguises: Sepa leholo ke la moet $i^{2}$ MLJ KOENANE ${ }^{3}$ AND KJ MAPHUNYE
}

\begin{abstract}
Violent or other attacks on nationals from other African states are a reality we have come to expect time-after-time in post-apartheid South Africa. We are once confronted with the ugly reality of barbaric and cruel acts of attacks on foreign internationals from other African states, which some have labelled "xenophobia" or "xenophobic attacks" while others term this "Afrophobia" (Black-on-Black conflict and violence directed at other Africans). We argue that this unsolicited characteristic of being African (indigenous) will never disappear unless the moral and political disguises thereof are dealt with radically and proactively. Generally, the subject of xenophobia is one which almost everyone has an opinion on - therefore this must be a subject close to every person's heart, be this controversial or not.
\end{abstract}

Keywords: Afrophobia, attitude, divide-and-rule, foreigner, hatred, power

2 Sepa leholo ke la moeti is the Sesotho expression which suggests that whenever anything goes wrong in a home, community or society, blame is attributed towards strangers or foreigners.

College of Human Sciences, University of South Africa, P.O. Box 392, Unisa, 0003, South Africa, Email: koenamij@unisa.ac.za

4 Inaugural WIPHOLD-Brigalia Bam Chair in Electoral Democracy in Africa at Unisa, .O. Box 392, Unisa, 0003, South Africa, E-mail: maphukj@unisa.ac.za 


\section{Introduction}

With the dawn of democracy in South Africa in 1994, the "Rainbow nation" espoused by retired Archbishop Desmond Tutu was usually perceived as a kind of nirvana or paradise based on the numerous rights and freedoms that were enshrined in its new constitution. These rights, which are enshrined in the Bill of Rights, include freedom of expression, rights to human dignity and equality, freedom of religion, belief and opinion, freedom from slavery, servitude and forced labour, right to life and freedom from torture, inhuman and degrading punishment (Constitution of South Africa, Bill of Rights ss. 7-39). Such elaborate rights and freedoms suggest that the country is a mature democracy in which these and other rights are sacrosanct and greatly respected. Ironically, the situation on the ground in many South African towns, townships, villages and other localities seems to point in another direction. At least since around the year 2000, there have been increasing incidents of hatred, negative attitudes and dislike of foreigners in general from Asian countries but specifically targeting African migrants from the different parts of the continent such as Somalia, Democratic Republic of Congo, Zimbabwe, Nigeria, Ethiopia Mozambique, Malawi, to name a few (ENCA, 2015). Violent attacks on other nationals or some forms of attacks on nationals from these and other African states are a reality we have come to expect time-after-time.

Once again, South Africa confronts the ugly reality of barbaric and cruel acts of attacks on foreign nationals from other African states. Some have labelled such phenomena xenophobic attacks while others conclude that this is nothing more than Afrophobia (Black-on-Black conflict and violence directed at other Africans). Mudimbe in his work entitled: The Invention of Africa (1988) bluntly points to the negative consequences of colonialism on the African soil. One way in which these consequences still haunt Africans is the tendency by some of them to look down on other Africans especially if they are from elsewhere in the continent. In the case of South Africa, the brutal systems of colonialism, racial segregation and apartheid had over centuries inculcated a negative attitude of disdain and hatred of fellow Africans from "beyond the Limpopo". During the apartheid era, many Africans who came to South Africa usually worked in the mines and factories. While this situation might have changed since the country's democratisation, relatively very few South Africans (especially Blacks) ventured beyond the borders of the republic in search of work partly because of the apartheid system's restrictive policies. The end results were that very few South Africans (especially Africans) clearly understood the socio-economic, cultural and political lifestyles of fellow Africans beyond the Limpopo.

We argue that this unsolicited characteristic of being African is never going to disappear completely unless the moral and political disguises are dealt with radically and proactively by all the role-players in South African society. In a sense, radically here means transforming the way we in South Africa do things, including dealing with all aspects of life in settings such as homes, religious and political gatherings and cultural and social meetings, to name but a few. Arguably, a child is born as an amoral and apolitical being who then is socialised into becoming anything we shape this child into be-ing, or what sociologists call socialisation. Child development depends very much on socialisation, which suggests that under ordinary circumstances, every child be-comes what they were taught or developed to be. The attitude they grow up with - that is, their moral outlook and perspective in life is generally what they 
were taught to be. To use Behavioural Theory, people are conditioned in their early childhood to become who they are at their later adulthood stage. We are yet to meet someone who is not in part or completely a product of their society. Letseka (2013: 351) views it thus:

Eventually, I offered my readers African traditional education and the Basotho
indigenous education as programmes we might draw onto to address the development of
the sort of personhood that is necessary for Ubuntu moral disposition. Justified my choice
of Basotho indigenous education on the grounds that is my own native education about
which I can write uninhibitedly. I surmised that young people who are initiated into
Ubuntu morality have the potential to become citizens that are inclined to treating
others with fairness at all times.

In many ways this further suggests that we are all socialised into becoming who we are as well as what we are by our environment. It is also true that we chose at some stage to out-grow certain tendencies we learnt from childhood. But even then, the fundamental reference point still largely remains that of the person's upbringing and essentially shapes their views later in life. As a result of this conviction, we believe that people can and must be educated on how to view the other person. First and foremost, we need to teach ourselves (even more so our young generation(s)) how to treat others as persons before we can notice differences.

Kollapen's primary concern regarding xenophobic actions against other Africans from across the borders (cited in Koenane 2013: 107) is that "not enough was done to understand the cause of these attacks". This equally applies to Afrophobia, the blatant hatred and dislike of Africans from other parts of the continent and this, fundamentally, disguises the crux of the matter; which is the basis of any disagreement and conflict. In order to come up with a working solution and reach a common ground the cause of any conflict must be understood. With regard to Afrophobia, probably everyone at the offices believes that they understand the causes of these atrocities. The most striking ones are the now familiar statements such as: "during the apartheid period in South Africa, we stayed in their countries" or "during our time of need in the apartheid era they hosted or welcomed us in their country". There is nothing wrong with these kinds of remarks but the problem is that these statements never made any difference before, they have had no impact in dealing with Afrophobic incidents in the past and might not make any positive contribution in the current state of affairs either. The apparent indifference of the South African society to such statements may be attributed to possible disjuncture between the country's leadership and ordinary citizens who do not understand why they must "share" their country with foreigners, irrespective of wherever they come from. It would seem that some South Africans believe their lives would have been better if foreign nationals were barred from coming to their country; but this belief is clearly false in our view.

\section{Xenophobia or Afrophobia as power relations}

The recent incidents of xenophobia/Afrophobia ${ }^{5}$ and their consequent attacks began in Durban, KwaMashu, and the City Centre and subsequently spread to iSiphingo and a vast

In this article, the two concepts xenophobia and Afrophobia are used interchangeably. We however, prefer Afrophobia since it emphasises that it is mostly Africans from other African countries who are 
number of places in KwaZulu-Natal. The general public (mostly people of goodwill and those whose lives and livelihoods are threatened) is concerned that sooner or later these attacks will spread to the rest of the country, probably targeting new "enemies" such as some other South African ethnic or racial groups. As such, we begin by defining the word xenophobia. For the purpose of this paper, the working definition of xenophobia is taken from Frank Bealey (1999: 344) it is formulated thus:

\section{A fear and hatred of foreigners often reflected in harassment of minority ethnic groups. It may begin as a dislike of people with strange dress and behaviour and develop into specific phobias [...]. Xenophobia may be particularly rife where a community or nation feels threatened.}

Xenophobia or resentment of foreigners is not a unique phenomenon to South Africa, perhaps what could be unique is the manner by means of which this resentment is expressed. Speaking at the Mail E Guardian and University of South Africa Critical Thinking Forum recently (23/04/2015), anti-apartheid stalwart and human rights activist, Advocate George Bizos, made the following remarks on the spate of attacks on foreign nationals in South Africa:

This isn't about fear of foreigners. This is far more malevolent than that: rather, we are dealing here with the hatred of foreigners - as the Greeks would call it, misos gia tous xénous.

Julia Kristeva in her book entitled Strangers to Ourselves (1991) articulates her own experience of being a foreigner in France. Nyamnjoh (2006: 38) asserts that xenophobia in all its different manifestations affects all societies but emphasises that not all foreigners became targets. Of note are certain elements which according to Bealey constitute a definition of xenophobia. Firstly, he mentions that "xenophobia is fear and hatred of foreigners". Insofar as we are aware both fear and hatred are real emotions, in a sense that people fear something and such a fear has its source. To begin with, he states "fear", we therefore would like to investigate if this is a justified fear or not. In other words, is it rational to fear? We believe that xenophobia/Afrophobia, is a reality which affects people differently and as such people hold different viewpoints about it. Contrary to the belief that xenophobia exists only among Africans, it is not only a problem in South Africa and among Africans only as seen in the current efforts by European countries to keep away Africans fleeing from North Africa through the Mediterranean to southern Europe. Thus, Afrophobia exists at all levels of life and it is expressed in different ways depending on the level at which it operates (Koenane, 2013). We also believe that such fear may or may not be reasonable (again depending on the level from which one finds him or herself). The importance of this investigation is that from a philosophical perspective, fear as an emotion is something neutral, that is, fear does not have any moral dimension on its own. It is only if it is judged as a justifiable or unjustifiable act where it adopts such a moral aspect to it. But again it is not as simple as it looks, since what is justifiable for one person may not necessarily be so for the other person. In other words, people may not necessarily agree with what constitutes justification for acting in a

always attacked by frustrated locals. We are aware of Pakistanis and other Asian nationals who are doing business in South Africa and who are usually victimised by xenophobic incidents. 
particular manner. Hence, what genuinely constitutes fear in one person may genuinely not necessarily constitute fear in another. However, Afrophobic incidents outline power relations.

Experience teaches us that no matter the progressiveness of a policy or a constitution, a migrant or a foreigner would not have as much comfort in a foreign land as though they were in their own country. In practical sense, power relations characterise the level of comfort a foreigner can enjoy. This again operates within given levels as suggested by Koenane (2013), where he outlines three levels on which Afrophobia is experienced and expressed. Koenane argues that these three levels are:

i. The lower level - which is mostly where the frustrations (reasonable or otherwise) lead to acts of vandalism, violence, attacks and looting. Simply put, at the lower level xenophobia is expressed in barbaric acts. This is the lower moral road.

ii. The second level is characterised by people who do not commit themselves but would simply opine that foreigners must not be attacked or killed as it is the situation in South Africa but that they must go back to their own countries; and indifferent people. This he calls the middle road but he does not commit himself into mentioning whether this is a moral or unethical way. However, in this paper, we would refer to this middle road as a moral disguise.

iii. He further maintains that the third level of xenophobia is a professional level in which violence and criminal acts do not necessarily play a role. Among foreigners in South Africa, there are those who are highly skilled and educated. There is high competition for positions at this level and more often than not these foreigners easily elbow locals aside because of their superior education and experience. In the case of Zimbabweans and to some extent Mozambicans, another factor we often hear is about "hard work". The binary used is that "South Africans are lazy compared to Zimbabweans and Mozambicans who are "hard workers". In other words, foreigners are knowledgeable, experienced and preferred to locals. Koenane (2013) suggests that the experience of these foreigners could be used to benefit South Africans who are at the same level of skills and education if and when these foreigners are meant to train and mentor South Africans to acquire skills and experience such as they have. He argues that this in his view is a more moral approach to establishing better relationships between foreigners and locals. For Koenane (2013), this is a high moral road.

The above differentiation reminds us that there are two different kinds of immigrants: voluntary and involuntary immigrants. Immigrants are of heterogeneous groups and their reasons for coming to South Africa vary. Nyamnjoh (2006: 38) rightly affirms that as much as xenophobia is experienced in all societies those who are targeted are chosen carefully by perpetrators, according to him, people are targeted in terms of the hierarchies in the society-. As such, voluntary immigrants are those who willingly go into a host country for different reasons in particular for greener pastures in terms of seeking professional jobs because of their education and skills. Most of those who belong to this group are those affected by xenophobia differently and are generally protected by law since they have work and residence documents which allow them to live in a host country legally. Among these are those who cross borders for economic reasons, usually also termed "economic migrants", even those with little education and little knowledge of this and that (that is, people with no specialised professions in a strict sense of the words - generally referred to as manual labourers). Most of these without specialised professions would also have no legal documents to be in a host country. As such, in most cases the dog-eats-dog situation, which is characterised by violence affects most of these unspecialised general labourers. Competition at this level is rife since 
there are normally thousands of unskilled job-seekers in a host country such as South Africa. Be that as it may, there is no moral justification for violating others' human rights whether they are in the country legally or not.

Involuntary immigrants are those who cross borders into other countries unwillingly, these are individuals who are forced by circumstances including political and other forms of persecution in their country of origin. Among these are those who are regarded as political refugees in terms of the United Nations (UN) High Commission for Refugees (UNHCR) Convention Relating to the Status of Refugees (1951) and its 1967 Protocol (UNHCR, 2010). Overall, political refugees are fairly educated but this differs from country to country and in Africa many refugees tend to be women from rural backgrounds who are illiterate (UNHCR, 2009: 48). Essentially, they are politically involved individuals who, because of their opposition to the ruling party in their country of origin, are then persecuted together with their families and as such are pressured into fleeing their own country into exile in another country ${ }^{6}$. Sometimes they are also forced to flee their countries of birth owing to internecine or civil wars, political instability, despotic or authoritarian regimes and myriad violations of their rights as specified under the Universal Declaration of Human Rights. We agree with Pogge (2006: 710) that governments have moral obligation and political responsibility to give such people a refugee status and South Africa is within its rights in terms of international law to accept refugees into its territory. Amnesty International (2002) confirms that a number of governments imprison, persecute and torture their political opponents. Since fleeing is one of the main reasons people live in exile, it bothers us that countries continue with political disguises by evading serious issues which ought to be addressed. Issues which make people flee their countries are generally political issues; as such political remedies ought to be found in addressing this particular problem.

In Africa, the African Union was established originally as the Organisation for African Unity (OAU) with a hope of addressing African problems head-on and to ensure that Africans throughout the continent are liberated from the yokes of slavery, colonialism and white minority governments that used to plague many parts of the continent. To what extent this is taking place, given the tendency of African governments to hide such matters within the cloaks of diplomacy and "national interest", is difficult to discern but it looks to us as though there is an avoidance strategy in dealing with real political problems which negatively impact on the continent. Yet, seriously addressing issues which pressurise people to flee their own countries would undoubtedly ensure that people are safe and protected and thus obviate the need to flee. This would further ensure political freedom and freedom of speech and other fundamental human rights that are often trampled upon easily by African governments. Furthermore, this would help to safeguard constitutional change of government through the holding of credible democratic elections that comply with international election management best practices. Incidentally, the African Charter on Democracy, Elections and Governance, which was adopted by the African Union in 2007, clearly stipulates the relevant steps that African governments must take to enhance democratic rule in their own countries (ACDEG,

However, there must be a an element of persecution and fear of such by anyone so defined. The UNHCR Convention Relating to the Status of Refugees (1951) defines a "refugee" as "someone who is unable or unwilling to return to their country of origin owing to a well-founded fear of being persecuted for reasons of race, religion, nationality, members of a particular social group, or political opinion" (UNHCR, 2010: 3). 
2007). In the end, the enforcement of this Charter is left to the same governments that usually drag their feet in implementing such agreements.

As the UN Convention for Refugees attests (UNHCR, 2010), it is not only political views that make people targets in their own countries; and, religion also plays a role in people fleeing their countries. In some cases, some religious groups and sects are usually persecuted for not participating in the political and other processes of their countries. Some religions have imposed extremely harsh penalties against their own members to such an extent that people would denounce their religion and flee for their lives. Again this is an issue which should be checked against compliance with national laws, continental instruments and international law since all people first and foremost belong to a state.

Evidence suggests that South Africa experiences several impediments to democratic consolidation, suggesting that the country is deply divided along "racial, ethnic and linguistic lines" (Gibson \& Gouws, 2000: 278). Similarly, it experienced political tolerance shortly after the demise of apartheid. This may not be dissimilar to the presence of political intolerance and religious oppressive laws in some African states which, inevitably, will require a political solution. Such a solution, however, does not imply that African governments must sweep blatant violations of human and democratic rights under the carpets and that, with collusion from western governments; they should pay lip service to the obligations of the Universal Declaration of Human Rights including African human rights obligations. Undoubtedly, the situation of people crossing borders legally or illegally to get jobs or make money from other countries would always be an urgent political problem which needs to be urgently addressed especially if it looks to insiders as though foreigners are preferred over them. ${ }^{7}$ Thus, there is need for robust political debate in South Africa which may lead to finding a sustainable political remedy to this situation. Unfortunately, extreme poverty is one of the characteristics of the new South Africa, resources are not enough for everyone and as such competition for these limited resources causes frustration on locals. Unemployment on all levels is a serious matter to an extent that competing as an underdog would always threaten one who is at the disadvantage.

\section{The mind set and xenophobia}

In his work, I Write What I Like, Steve Biko (1978) argues that the most powerful weapon at the hands of the oppressor is the mind of the oppressed. This is further supported by Mzwakhe Mbuli in one of his songs where it states: ukulimala kwenqondo ukulimala komuntu. Literally, this means that once the mind of the human being is damaged the whole person is damaged beyond repair. In simple terms, this article argues that the problems about certain systemic structural rules of engagement are deep-seated in the minds of individuals. Certainly, xenophobia manifests itself differently - this depending on the level at which it operates. However, in all its manifestations xenophobia has everything to do with power relations. Power relations, which are some of the main causes of Afrophobia, reasonable or unreasonable, were entrenched initially through a well-orchestrated project of the apartheid

Anecdotal evidence and public talk in taxis, buses, trains and other public forums suggests that some employers do not always hide their preference for foreign nationals in certain industries especially hotels and catering, construction and agriculture. Observation by the authors on the nationality of individuals employed in some major retail, hotels and catering outlets in cities such as Johannesburg, Pretoria and Cape Town suggests that (unstated or unofficial) preference by these outlets is disproportionately leaning towards foreign nationals. 
regime namely the divide-and-rule strategy mostly based on race and ethnicity. This strategy worked and some South African leaders and elsewhere in the continent may have found it appealing as a means to prolong their stay in power.

During the apartheid era, the so-called Black-on-Black violence, which was essentially orchestrated by the regime, was an effective tool which the apartheid government used to its advantage to undermine genuine and organised resistance to its illegitimate rule and draconian policies. In order for this violence to take effect, the apartheid regime had to ensure that the divide-and-rule strategy was in place by carefully co-opting collaborators and elements from the former Bantustans who were forced to accept the legitimacy of apartheid in return for concessions from the then White-dominated government. How the strategy worked was simply to turn Africans against each other. For instance, one group was made to believe that they were "better" than the others and thus "superior", while at the same time the same group which was made to believe they were "better" was reported to other Black groups as a "sell-out" group. As a matter of fact envy and jealousy were the order of the day, these groups began to hate one another and the hatred aggravated to a deeper level. Individuals from these different groups began to see others as enemies, which must be defeated or perpetually undermined; and, in a true Sartrean sense, Afrophobia is an act of viewing the other Africans as "hell". This is typified by the negative naming of the other which is expressed differently using derogatory terms such as: makwerekwere, izifikanemithwalo, matswantle, etc. (Koenane 2013: 106).

In terms of the apartheid psyche or ingrained attitudes, a concerted attempt was made by consistent state propaganda and disinformation campaigns to discredit African "beyond the Limpopo" by painting a picture of "backwardness, violence and death". This was often done through biased films, radio broadcasts and newspaper articles. Thus, many South Africans grew up either hating people from such countries or at least being suspicious of their presence within their midst. The anti-apartheid war against the state, while it ultimately exposed the bankruptcy of the apartheid laws and policies nevertheless did not help much in demystifying many stereotypes created by the apartheid regime.

Most often than not, cultures embody attitudes towards others in particular those who do not belong to "our own group(s)", which is a manifestation of the "us and them" syndrome. Xenophobic attitudes have everything to do with the mind-set, negative in this case. For instance, among the Basotho culture, there is a proverb which largely expresses an attitude towards foreigners or strangers as follows: "Sepa lebolo ke la moeti [...]". Current and past xenophobic attacks and attitudes in South Africa are characterised by allegations and accusations of foreigners engaging in criminal acts. Making foreigners scapegoats for things which go wrong is a hypothesis which most authors have explored (Wilson, 2015). These include taking out frustrations on foreigners for poor service delivery (Fauvelle-Aymar \& Segathi cited in Landau 2011: 59). In other words, foreigners are blamed for crime and political failures which they too have no control over. Evidence of this is elucidated by Landau (2011: 9-10) wherein he quotes the late Joe Modise's (the then Minister of Defence) utterance where he remarked thus:

As for crime, the army is helping the police to get rid of crime and violence in the county. However, what can we do? We have one million illegal immigrants in our country who 
commit crimes and who are mistaken by some people for South African citizens. This is the real problem (Landau, 2011: 9).

This statement can be read together with that of Billy Masethla, who proposed that strong action must be taken against criminals. Masethla asseted as follows:

Approximately 90 per cent of foreign person who are in $R S A$ with fraudulent documents, ie, either citizenship or migration documents, are involved, in other crimes as well ... it is quicker to charge to these criminals for their false documentation and then to deport them than to purse the long route in respect of the other crimes that are committed (Landau, 2011: 10).

Accodingly, both this statemen are convinced that foreigners are a problem since most of them are criminal elements that should be taken care of. Foreginers are equated with crime thus Sepa le holo ke la moeti. Evidently foreginers are blaimed for everything that goes wrong It is for this reason the authors argue that all efforts to address xenophobic attitude and violence is a political disguise.

Kristeva (1991) differentiates between citizenship and foreignness. In her work: Strangers to ourselves, Kristeva (1991: 95) asks the question: "by what right are you a foreigner?" She then moves on to what she terms jus soli, jus sanguinis. She is basically concerned with that which constitutes a foreigner or put differently, she wonders how best we could define a foreigner. She explores all sorts of avenues, could a foreigner be someone who does not belong to a particular group? Or is the foreigner someone born in another country (Kristeva, 1991: 95). She maintains that in terms of a foreigner, two legal systems were created. Firstly the jus soli, which is Latin for the right of the territory; she refers to the right by which nationality or citizenship can be recognised. Secondly, the jus sanguinis this refers to the rule through which birth in a state is sufficient to confer nationality, irrespective of the nationality of one's parents. Both definitions suggest some new definition of a nation state in which the foreigner has no place. Analysing the situation from her European context, Kristeva (1991) is curious at how foreignness attracts such negativity and fear. She further articulates that the possibility of threat or benefit from the other (foreigner) dictates what rights are offered to him or her.

On the lower level in respect of education, self-reliance and skills, the assumption is that the other (foreign nationals) must not have rightsand must be excluded from public service. In terms of the power relations argument propounded in this article, this is a typical example wherein the powerful (police or the state in this case) clearly prey on the powerless ("undocumented" or illegal migrants). Such practices have deep roots in the modus operandi of the South African Police during apartheid whereby virtually all Africans or black people were generally presumed guilty until proven otherwise. During such encounters, police brutality at its worst including the indiscriminate unleashing of police dogs on Africans was the norm in many black townships. We find this disturbing and, therefore, we believe that something should be done to legitimise the stay of Africans from other parts of the continent in the country and thus extend legal protection to them as well.

\section{Empty rhetoric and political disguises}

Xenophobic attacks and incidents of violence against African others occur year-in and yearout. We hear the same rhetoric every time these incidents occur; this rhetoric has up-untilnow had no impact and has not made any difference. This leads us to ask this question: is our 
government serious about curbing xenophobia among South Africans? The new rhetoric reads as follows: \#SayNoToXenophobia and \#Simunye - Africa Unite. However, as the word suggests, rhetoric implies hollow promises or verbal declarations that are not backed by concrete action. Some South Africans anecdotally acknowledge this rhetoric but ascribe it to the fact that "foreigners cannot win votes", alluding to the fact that politicians from the governing African National Congress (ANC) and the opposition are not always that enthusiastic about issues pertaining to Afrophobia and xenophobia since foreign nationals are legally barred from voting. If this view is correct, it might serve as partial explanation to the apparent official lethargy or reluctance to take meaningful action in dealing with this phenomenon that continually keeps embarrassing the country (ENCA, 2015; Wilson, 2015).

With a few slogans, radio, television and print media campaigns that have been undertaken in 2008 and in 2015 when the attacks against other Africans occurred, we ask the question: Is this the best we can come up with? To answer these two questions, it appears that not enough is done to stop these xenophobic attacks. The attacks are mainly directed to the vulnerable sections of foreigners living in South Africa, that is, those in the lower level of the economy, those without specialised skills or education, those who do not have legal documentation to be in the country.

In every country, issues of development are of primary concern for government, particularly in developing countries. Therefore, in order for development to effectively take place, a country should have a reliable estimation or accurate population statistics of people living in the country, which includes foreigners living in a given country. As observers have argued, this is part of the usual requirements of good governance that governments are expected to comply with (Davids, Theron \& Maphunye, 2005: 64). South Africa is no exception in this regard. Arguably, therefore, those entering the country illegally render development efforts ineffective as this strikes at the heart of development and economic planning aimed at providing services for all citizens. This problem thus needs to be addressed. In cases where foreign nationals are properly documented, we believe xenophobic attacks would be minimised since these foreign nationals are protected by law. However, this means that all the other variables will also have been taken care of such as corruption among state officials such as police, other security agencies and Home Affairs employees. This applies equally to illiteracy, high unemployment and poverty. Kristeva (1991: 96) writes:

If political regulations or legislation generally speaking define the manner in which we
posit, modify, and eventually improve the status of foreigners, they also make up a
vicious circle for it is precisely with respect to laws that foreigners exist. Indeed without
a social group structured about a power base and provided with legislation, that
externality represented by the foreigner and most often experienced as unfavourable or
at least problematical would simply not exist.

We agree with Kristeva (1991) that taking care of what exposes foreigners to exploitation of any sort and legalising their stay in the country is for us the first step in the right direction. This would further provide foreigners with political rights thus making them responsible members of society with rights and obligations like all other nationals. In this way, South Africa would in a true sense of the word belong to all who live in it. What Kristeva (1991) and Wilson (2002) later on challenge us to do is to work towards self-knowledge or selfrealisation of who we are. Wilson in the book with a similar title as that of Kristeva: Strangers 
to Ourselves argues that in order to know ourselves better, we need to find a way of discovering our unconscious selves. He further articulates that for one to know oneself, and how one feels all one needs to do is to take into consideration what one actually does. In other words, our actions define who we are or what we are. Put differently, xenophobic acts define South African culture in terms of our relationship with Africans from within the continent. Xenophobic incidents stigmatise South Africans in general. They define South Africans as intolerant, violent, heartless and generally brutal to those speaking different language(s) especially if these come from another African country. This, to some extent, exposes the hypocrisy and essence of the so-called 'xenophobia' as being actually "Afrophobia". For instance, we have hardly witnessed any incident wherein refugees from the former Eastern Bloc countries such as Czechoslovakia, Bosnia-Herzegovina, Slovenia, and other former Yugoslavian territories were exposed to acts of "xenophobia". Yet some from such countries have over the years settled in South Africa and were readily accepted as "Whites". They may not have settled in some African township or village but in this case it would appear that the Black-White binaries of the South African society seems to have ascribed a "superior" (White) status to them unlike the African migrants who bore the brunt of blatant discrimination.

Treating others differently with a view to discriminate unfairly against them is a deep-seated problem among Africans in particular (ENCA, 2015). For example, the Zulu people in deep KwaZulu-Natal would refer to any Sesotho speaking groups as izilwanyana (little animals); check this out, they are not even animals but little animals because they consider them to be inferior, a negative ethnic mind-set which Steve Biko cautioned against when he coined the slogan: "Black man, you're on your own"10. This kind of attitude is also reflected in Hugh Masekela's hit song, Chileshe, in which he cautions against looking down on others, calling them derogatory names and treating them in any inhumane manner. In the song the Zulu people represented by Ngobese refer to others as izilwanyane (little animals). Interesting enough, in the song, Dlamini (representing the Swazi people refers to others as abantu bezizwe (foreigners) or those who belong to other cultures. Again, referring to other Africans as foreigners is clearly not acceptable to Masekela. Technically, it does not make sense to call Africans foreigners anywhere in Africa - this is their mother continent divided by artificial borders created or invented by colonisers at the 1884 Berlin Conference. Frankly, attitude and prejudice are learnt or acquired, but most importantly they are internalised. It is for this reason that we argue that people could be taught early on in their lives to adopt a positive attitude towards others. Furthermore, the country does not deserve the rhetoric and apparent indifference by politicians from all political formations as this has clearly proved ineffective and suggests that South Africans merely criticise Afrophobic acts whilst in principle not doing much that is sustainable in practice. Our approach also urges all individuals and civil society organisations to assist the state to address the manifestations of negative attitudes and prejudice among their compatriots, (ENCA, 2015; Wilson, 2015).

\section{Way forward}

Avoidance strategy is in our view fuelling incidents of xenophobia and Afrophobia in South Africa. This avoidance strategy is what we earlier referred to as political disguise. Political disguise is understood as a political strategy to refuse or avoid addressing pressing issues such 
as immigration policies in the name of maintaining good relations with other countries. We believe that every child is born amoral that is without a sense of morality; as such, morality in human beings is something people learn as they grow up. We therefore believe that introducing moral education from early age schooling would make a difference in terms of people's attitudes- towards others. In this respect, all approaches to moral education would be of great help especially Aristotle's approach of character ethics. The reason we advocate for Aristotle's virtue ethics is simply that it emphasises the character of the moral agent. Since it emphasises the character of the moral agent, it thus presupposes character formation. Better citizenship and sensitivity towards the other could be established earlier in the moral formation of our children.

Kristeva (1991: 97) moves on to note that as much as certain groups whose philosophy is based on Stoicism and the Judeo-Christian religion have offered some equal status and equal rights to foreigners these are only realistic in a spiritual city since another set of group is created to exclude foreigners from benefiting from the country's resources. Like Kristeva (1991), we believe that this is where the political power or the state in its broader sense should play its role. How the political order plays its role is for us a serious moral matter. Certainly, politics has everything to do with distribution or allocation of limited resources in a given country. Some believe that charity begins at home; by this, the respondents meant that these scarce resources must benefit South Africans in the legal sense of jus soli; jus sanguinis. This theory obviously excludes foreigners, therefore where these foreigners benefit from the country's resources, locals are inevitably frustrated, jealous and strategize and react by victimising the foreigners who seem to be benefitting disproportionately from government interventions such as RDP (Reconstruction and Development Programme) houses and small business initiatives especially in the Black townships and villages (Wilson, 2015).

The question of resources raises another serious question for Julia Kristeva (1991). She asks: do we have rights as men and women or as citizens? She argues that insofar as resources or rights are allocated in terms of a citizen and a non-citizen, it is equal to recognising one as fully human while the other, a non-citizen, is regarded not as a human being (Kristeva, 1991: 98). Kristeva (1991) additional emphasises that the idea of exclusion is closely connected with the idea of nation-state, as such she recommends two solutions to this problem. First, she recommends the global united states of all former nation-states where the rights of all human beings are integrated. Second, she recommends small political sets designed by humanistic cosmopolitanism with a statute introduced to protect the rights of foreigners (Kristeva, 1991: 98). Certainly, Kristeva's (1991) view is not new to Africa. It seemingly reminds us of the ideas of the pioneers of the Organisation of African Unity (OAU) in 1963 when the likes of Kwame Nkrumah of Ghana were strongly advocating for a "United States of Africa" and a continent free from colonialism and White minority rule. Of course, probably owing to the reformism from which the OAU subsequently suffered, the question of the borders fell out of its agenda (AU, 2002). In 2002 when the Organisation of African Unity became the African Union, such ideas again surfaced but Africans are still awaiting to see the full commitment and political will of all their governments to such ideas. Thus, Kristeva's (1991) argument is not far-fetched. However, the greatest challenge will be on the nature and development of such a "United States of Africa" including the actual types of "small political sets designed by humanistic cosmopolitanism". 
In Koenane (2014: 2) discusses what she refers to as self-defeating behaviour. We therefore believe James' theory of self-defeating behaviour applies perfectly well in acts of xenophobia and Afrophobia (regarded by many as Xenophobia). Accordingly, reacting also has some selfdefeating consequences as well. Consequently, understanding Kristeva's analysis of "Strangers to ourselves", she maintains that we are strangers to ourselves and that which we fear in ourselves needs to be dealt with and accepted in others for us to be able to understand and accept the stranger in others. The growing frustration on other things such as joblessness, scarce resources and political failure to provide services are not reasons enough to take out the frustration on innocent people from other African countries or elsewhere in the world. A xenophobic and Afrophobic environment has been allowed to exist for a long time now; and, this environment breeds all kinds of violations and criminal activities ranging from rape, looting, violence, inhumane treatment of others and many other injustices against foreigners who are perceived by locals as a serious threat. Yet, the capacity of the state to deal with all these acts of criminology and lawlessness also needs to be brought under scrutiny here. Why, for instance, do we constantly see incidents of locals appearing on national television and print media looting "foreigners' shops" and yet seeing police standing idly by when such acts are perpetrated? (ENCA, 2015; Wilson, 2015) Why have we not seen any prosecutions of the perpetrators of the 2008 violence against foreign nationals, many of whom also appeared daringly on national television? (ENCA, 2015). The answer can only point to the fact that South Africa's state is increasingly becoming "soft" or weak and therefore incapable of addressing such crises. This, for us, also accounts for the current crisis and dilemma facing the country in terms of xenophobia and Afrophobia.

As much as other scholars express their disillusion regarding Ubuntu as a concept on which a South African identity could be established, we argue that given the idea that Ubuntu emphasises certain character traits that only could promote friendliness, caring and values that could foster good behaviour, it is our duty to promote the idea of Ubuntu and teach young people from early on in their lives to cherish Ubuntu ideals. In supporting the ideals of Ubuntu Landau (2011: 229) writes:

While the emphasis on a just and caring society reflects an implicit criticism of capitalism's inhumanity, [...], Ubuntu's action plan - helps shroud a demon to create national cohesion means to overcome difference in a country which, if nothing else, is characterised by difference.

Therefore we believe Ubuntu values cannot be discarded that easily as most scholars argue that these are needed to establish a cohesive South African cultural identity. We believe that from a moral perspective, South Africa needs strong leadership that would pave the way in dealing with xenophobia systematically and sustainably. We further need clear policies in terms of dealing with xenophobic incidents in their manifestations. Unless tough action is taken against xenophobia in all its manifestations, these incidents will reoccur and define South Africa for ages to come. The negative attitude and lack of trusting the other has characterised South Africa for a long time. MacIntyre (2007) argues that behaviour cannot be characterised independently of intention. If MacIntyre's assertion is correct, then xenophobic/Afrophobic violence and attitude must have an intention - it is this intention which must be uncovered. We likewise believe that incidents of violating the other such as Afrophobia attacks, violence, looting and killings would stop if in our school curricula, subjects and modules that are directed at shaping the lives of South African citizens are introduced from early on and are carried through. Akinpelu (1981) rightly argues that any system of education would not necessarily change people but education gives individuals an 
opportunity to make informed choices and further enables them to internalise what they have been taught and personalise it.

Political will is another critical part of the equation because once the political will and determination on the part of leaders is strong enough, Afrophobia in all its manifestations its related incidents would be addressed effectively. Such political will is quite critical given the fact that whenever the leadership does not seem to prioritise an issue, the general public might erroneously assume that such issue is unimportant. ${ }^{11}$

Finally, we believe that borders we invented to with an intention to divide Africa, and if Mudimbe's thesis of The Invention of Africa is correct, then the new Africa could be reinvented by eliminating borders and allowing Africans to move freely in the continent without the hindrance of visas and other such hurdles to freedom of movement. We similarly believe that Africans must be allowed to have unconditional dual or multi-citizenship in Africa. Furthermore we suggest that addressing all the real issues that affect Africans with honesty will contribute positively towards solving the problem such as Afrophobia - this is indeed working towards what Landau calls exorcising the demons within. Exorcising the demons from within would be the most moral thing to do than adopting the political and moral disguise strategies which in our view are not sustainable solutions to the current intractable problems facing African migrants in South Africa and elsewhere in the continent.

\section{Conclusion}

Afrophobia remains a threat to Africa's long-term stability. However, serious efforts, which will address the concerns of locals in South Africa and other countries, have not yet taken place. This is informed by the fact that most countries react instead of addressing the issue proactively. Countries affected by border problems need to adopt different strategies than just empty political disguises and rhetoric.

It was pointed out that in most situations, the Basotho proverb "Sepa leholo ke la moeti, [...]" is just a strategy to escape blame and apportion it on someone else especially a stranger; which is a way of avoiding confronting a problem. We believe this Basotho expression does not always reflect or express truth. Foreign nationals cannot be a scapegoat for all social ills that South Africa is confronted with. Like other crises situations, we all need to learn lessons regarding things that should not happen in our history. This prevailing hostility between Africans leaves families broken and destroy trust among Africans, xenophobic incidents in South Africa have proven that no one is the winner; we all become losers at the end.

Fighting Afrophobia is not an individual responsibility; and, it is a responsibility of the entire society. It is for this reason that the leadership, traditional, political and religious and from other civil society sectors, must lead the way. Failing to address this from the leadership perspectives may mean that we have weak leadership morally and politically. We argued that with the introduction of certain subjects and modules in our education system, citizens' lives may be shaped and that this is important towards shaping the attitudes of society towards

11 In April 2015, Zulu King Goodwill Zwelithini was quoted as saying: "We ask that immigrants must take their bags and go where they come from" (ENCA, 2015). Following these comments, official response from the highest echolons of government was muffled and no forceful message was sent out to condemn such anti-foreigner sentiments. Instead, the official line was that the King was "misquoted"; hence there was need to "investigate" what the monarch really said. 
others. We further argued that in order for South Africa to achieve its objectives in terms of fighting xenophobia, we need true political will and strong determination on the part of our leaders including pro-active initiatives by political parties and all role-players.

\section{Recommendations}

We suggest that serious political remedies ought to be found in order to address this problem which, as we have established, does not affect South Africa alone. We therefore suggest that it is time a sustainable political solution is found to the problem of borders, which was apparently shelved when the OAU decided to tackle the challenges of colonialism in Africa. We suggested that borders in Africa must be abolished for Africans to be allowed free movement in the continent. However, we insist that this must be accompanied by African governments' compliance with all the relevant continental and international instruments such as the Universal Declaration of Human Rights and the African Charter on Democracy, Elections and Governance, among others. Such instruments, we maintain, essentially seek to promote free, just, and democratic rule which will subsequently deter citizens from fleeing from one polity to another. Finally, an effective strategy that would eradicate xenophobic attitudes and behaviours at all levels is recommended but may not be an immediate feasibility given the factors raised here.

\section{References}

ACDEG, 2007. African Charter on Democracy, Elections and Governance, African Union Commission. http://www.africa-union.org/rot/au/Documents/Treaties/treaties.htm [Accessed: 11 May 2015].

Akinpelu, J.A. 1981. An Introduction to Philosophy of Education. London and Basingstoke: MacMillan Press Ltd.

Amnesty International, 2002. Report 2000. Baltimore: Lucas Publishers.

African Union (AU), 2002. Transition from the $O A U$ to the African Union. http://www.au2002.gov.za/docs/background/oau_to_au.htm [Accessed: 30 May 2015].

Bealey, F. 1999. The Blackwell Dictionary of Political Science: A user's Guide to its Terms. Malden, MA: Blackwell Publishers.

Biko, S.B. 1978. I Write What I Like: 1946-1977. London: Heinemann Publishers.

Davids, I. \& Maphunye, K.J. 2005. The public sector: Promoting development and good governance. In Davids, I., Theron, F. \& Maphunye, K.J. (eds.), Participatory Development in South Africa: A Development Management Perspective. Pretoria: Van Schaik.

ENCA, 2015. Checkpoint. eNerws Channel, 31 May 2015.

Fauvelle-Aymar, C. \& Segatti, A. 2011. People, space and politics: an exploration of factors explaining the 2008 anti-foreigner violence in South Africa. In Landau, L.B. Exorcising the Demons Within: Xenophobia, Violence and Statecraft in South Africa. Johannesburg: Wits University Press.

Gibson, J.L. \& Gouws, A. 2000. Social identities and political intolerance within the South African mass public. American Journal of Political Science, 44(2): 272-286. 
Koenane, M.L.J. 2013. Xenophobic attacks in South Africa - an ethical response: Have we lost the underlying spirit of Ubuntu? International Journal of Science, Commerce and Humanities, 1(6): 106-111.

Koenane, M.L.J. 2014. Towards an ethical contextualisation of Freud's theory of personality. Phronimon, 15(1): 1-15.

Kristeva, J. 1991. Strangers to Ourselves. LS Roudiez, New York: Columbia University Press.

Landau, L.B. (ed.). 2011. Postscript: positive values and the politics of outsiders. In Landau, L.B. (ed.), Exorcising the Demons Within: Xenophobia, Violence and Statecraft in South Africa. Johannesburg: Wits University Press.

Letseka, M. 2013. Anchoring Ubuntu morality. Mediterranean Journal of Social Sciences. 4(3): 351-359.

MacIntyre, A. 2007. After Virtue, $3^{\text {rd }}$ edn. London: Gerald Duckworth \& Co. Ltd.

Mail \& Guardian and University of South Africa Critical Thinking Forum, 2015. "Bizos: 'I know, too, what it means to be a foreigner'”. http://mg.co.za/article/2015-04-23-bizosi-know-too-what-it-means-to-be-a-foreigner [Accessed: 30 May 2015].

Mudimbe, V.Y. 1988. The Invention of Africa: Gnosis, Philosophy, and the Order of Knowledge. Blooming and Indianapolis: Indiana University Press.

Nyamnjoh, F.B. 2006. Insiders and Outsiders: Citizenship and Xenophobia in Contemporary Southern Africa. London and New York: CODESARIA Books in Association with Zed Books.

Pogge, T. 2006. Migration and poverty. In Gooding, R.R. \& Pettit, P. Contemporary Political Philosophy: An Anthology, $2^{\text {nd }}$ edn. Malden, MA: Black Publishing.

UNHCR, 2009. UNHCR Statistical Yearbook. www.unhcr.org/ [Accessed: 08 October 2015].

United Nations High Commission for Refugees (UNHCR), 2010. Convention and Protocil Relating to the Status of Refugees. Geneva: UNHCR.

Wilson, T.D. 2002. Strangers to Ourselves: Discovering the Adaptive Unconsciousness. Boston, MA: Harvard University Press.

Wilson, K. 2015. Analysis: Are Foreigners Stealing Jobs in South Africa? https://www.africacheck.org/...analysis_are_foreigners_stealing_jobs_in_south_africa / [Accessed: 08 October 2015]. 